\title{
Larval trematodes Paronatrema mantae and Copiatestes sp. parasitize Gulf of California krill (Nyctiphanes simplex, Nematoscelis difficilis)
}

\author{
José Raúl Morales-Ávila ${ }^{1}$, Jaime Gomez-Gutierrez ${ }^{1, *}$, \\ María del Carmen Gómez del Prado-Rosas ${ }^{2}$, Carlos J. Robinson ${ }^{3}$ \\ ${ }^{1}$ Instituto Politécnico Nacional, Centro Interdisciplinario de Ciencias Marinas, \\ Departamento de Plancton y Ecologia Marina (CICIMAR), Avenida IPN s/n, La Paz, Baja California Sur 23096, Mexico \\ ${ }^{2}$ Laboratorio de Parasitología, Departamento Académico de Biología Marina, Universidad Autónoma de Baja California Sur, \\ Apdo. Postal 19-B, La Paz, Baja California Sur 23080, Mexico \\ ${ }^{3}$ Instituto de Ciencias del Mar y Limnología, Universidad Nacional Autónoma de México (UNAM), Mexico City, DF 04500, \\ Mexico
}

\begin{abstract}
During 4 quantitative-systematic oceanographic cruises at 99 sampling stations in the Gulf of California (January and July 2007, August 2012, and June 2013), we found 2 trematode species (non-encysted mesocercaria stage) parasitizing the hemocoel of 2 krill species at nearshore locations. Copiatestes sp. parasitized Nematoscelis difficilis in January 2007, and Paronatrema mantae parasitized Nyctiphanes simplex in July 2007. Both trematode species had an intensity of 1 parasite per host. This is the first endoparasite known for $N$. difficilis, the first record of $P$. mantae infecting zooplankton, and the first confirmed trematode parasitizing krill species in the Gulf of California. We provide quantitative evidence that these 2 trematode species infect krill with considerably low station prevalence $(0.03-0.16 \%)$ and low population abundances $(<1.2$ trematodes $1000 \mathrm{~m}^{-3}$ ). A review of trematodes parasitizing krill indicates that syncoeliid trematodes also have (with few exceptions) low population densities and prevalence and lower species diversity than previously thought (suggesting a broader zoogeographic distribution range of these parasites). Due to the low host specificity of syncoeliid trematodes that typically infect more than 1 secondary intermediate host species in their complex life cycle, we propose that $N$. simplex and $N$. difficilis are intermediate hosts (although non-conspicuous) for the transmission of syncoeliid trematodes in the Gulf of California.
\end{abstract}

KEY WORDS: Digenean trematoda $\cdot$ Endoparasite $\cdot$ Mesocercaria $\cdot$ Metacercaria $\cdot$ Syncoeliidae Paronatrema mantae $\cdot$ Copiatestes $\cdot$ Krill $\cdot$ Gulf of California

\section{INTRODUCTION}

Nyctiphanes simplex Hansen, 1911 and Nematoscelis difficilis Hansen, 1911 (Crustacea: Euphausiacea) are the 2 most abundant euphausiid (krill) species distributed in the northwest coastal waters of Mexico (Brinton \& Townsend 1980, Brinton 1981, Lavaniegos-Espejo et al. 1989, Gómez-Gutiérrez et al. 2010, 2012a,b). Although the 2 krill species coexist in the Gulf of California, they show several biological and ecological differences: $N$. simplex is omnivorous, $<19 \mathrm{~mm}$ in total length, has a subtropical and neritic zoogeographic pattern, is highly abundant throughout the year, and forms large and dense aggregations and schools. $N$. difficilis is omnivorous with large body size ( $<22 \mathrm{~mm}$ total length), large bi-lobulated eyes, and strong periopods, suggesting voracious predator activity. This species is distributed in a transoceanic belt pattern at midlatitudes in the northeastern Pacific Ocean and Gulf 
of California (with subarctic and oceanic zoogeographic patterns), and it is moderately abundant, forming small and relatively low density aggregations (Kanaeva \& Pavlov 1976, Brinton \& Townsend 1980, Gómez-Gutiérrez et al. 2010). Because krill attain high population abundance and form dense social aggregations, they are a dominant component in the epipelagic food web as a major biomass link among primary producers and multiple zooplanktonic and nektonic predators (Kanaeva \& Pavlov 1976, Brinton \& Townsend 1980, Notarbartolo-diSciara 1988, Gendron 1992, Sampson et al. 2010). Their high abundance and biomass also make them potentially significant vectors of trophically transmitted helminth parasites (Trematoda, Cestoda, Acanthocephala, and Nematoda). Although krill are parasitized by all types of helminths (Shimazu \& Oshima 1972, Shimazu 1975, 2006, Shimazu \& Kagei 1978, Gómez-Gutiérrez et al. 2010, Gregori et al. 2012, 2013), in Mexico there are only 2 previous records of helminths infecting krill, namely N. simplex in the Gulf of California (Gómez-Gutiérrez et al. 2010) and Euphausia americana Hansen, 1911 in the Caribbean Sea (González-Solís et al. 2013).

To date, only 15 studies have reported infections of krill by trematodes (most of them accidentally discovered), for a total of 42 trematode records (8 genera, 10 species, and multiple non-identified species) parasitizing 12 of the 86 extant krill species known worldwide (Table 1). Systematic and quantitative studies focusing on parasites of krill, rather than opportunistic or sporadic discoveries, will increase our knowledge of parasite diversity, biology, and ecology, and particularly our understanding of parasite distribution, densities, and prevalence patterns, and how krill interact with their prey and predators as a vector of parasites in the pelagic food web.

Here, we report on 2 trematode species of the family Syncoeliidae that parasitize 2 numerically abundant krill species, $N$. simplex and $N$. difficilis, that were systematically collected during 4 oceanographic cruises carried out in the Gulf of California under contrasting seasonal conditions. We discuss the ecological relevance of krill as intermediate planktonic hosts for trematodes to complete their complex life cycle based on trematode developmental stages previously recorded, parasite-host population densities, and prevalences. Finally, we compare the occurrence of these 2 trematodes to other records of helminths parasitizing krill species in the Gulf of California and worldwide to provide an integrated quantitative perspective about the frequency of such infections in krill populations in nature.

\section{MATERIALS AND METHODS}

\section{Field sampling and laboratory analysis}

Krill were collected at 99 zooplankton-sampling stations during 4 oceanographic cruises (January and July 2007, August 2012, and June 2013) carried out aboard the RV 'El Puma' (Universidad Nacional Autónoma de México, UNAM) in the central Gulf of California (Fig. 1). Zooplankton was quantitatively sampled with oblique tows of a standard Bongo net (equipped with 333 and $500 \mu \mathrm{m}$ mesh net, $3 \mathrm{~m}$ long, and $0.6 \mathrm{~m}$ mouth diameter). Each net was equipped with a digital flowmeter (General Oceanics) to estimate volume of filtered seawater (Smith \& Richardson 1979). We analyzed the $500 \mu \mathrm{m}$ mesh net samples, which were fixed with non-denatured $96 \%$ ethanol. All developmental phases of krill (calyptopis, furcilia, juvenile, and adult) were sorted from the zooplankton samples and were cleared with a $5 \%$ dilution of $70 \%$ glycerin-ethanol to identify them (Baker et al. 1990, Brinton et al. 2000) under a stereoscope (Stemi SV11, Carl Zeiss) equipped with a calibrated micrometer. Krill specimens were counted and classified by species, sex, and development phase. Each krill specimen was dissected with entomological needles to record the presence/absence of helminths. We recorded the intensity (number of individuals of a particular parasite species observed parasitizing each krill host) (Bush et al. 1997). Krill and endoparasite trematode abundances were standardized to ind. $1000 \mathrm{~m}^{-3}$ to estimate population abundance (PA) of the hosts and the parasites in the sampled water column (Smith \& Richardson 1979):

$$
\mathrm{PA}=\left(\frac{a}{f v}\right) \times 1000
$$

where $a$ is total number of healthy krill specimens (without trematode infection) in each sample to estimate total krill abundance (excluding calyptopis stage) or is the total number of trematodes parasitizing krill specimens in each zooplankton sample to estimate total trematode abundance, and $f v$ is the net-filtered seawater volume expressed in cubic meters $\left(\mathrm{m}^{3}\right)$, calculated according the method described by Smith \& Richardson (1979). These abundance estimates allowed us to calculate the absolute prevalence (AP, scaled to percentage) recorded at each sampling station:

$$
\mathrm{AP}=\left(\frac{D_{p}}{D_{h}}\right) \times 100
$$

where $D_{p}$ is the density of the parasite (ind. $1000 \mathrm{~m}^{-3}$ ) and $D_{h}$ is the density of the krill host (ind. $1000 \mathrm{~m}^{-3}$ ). 


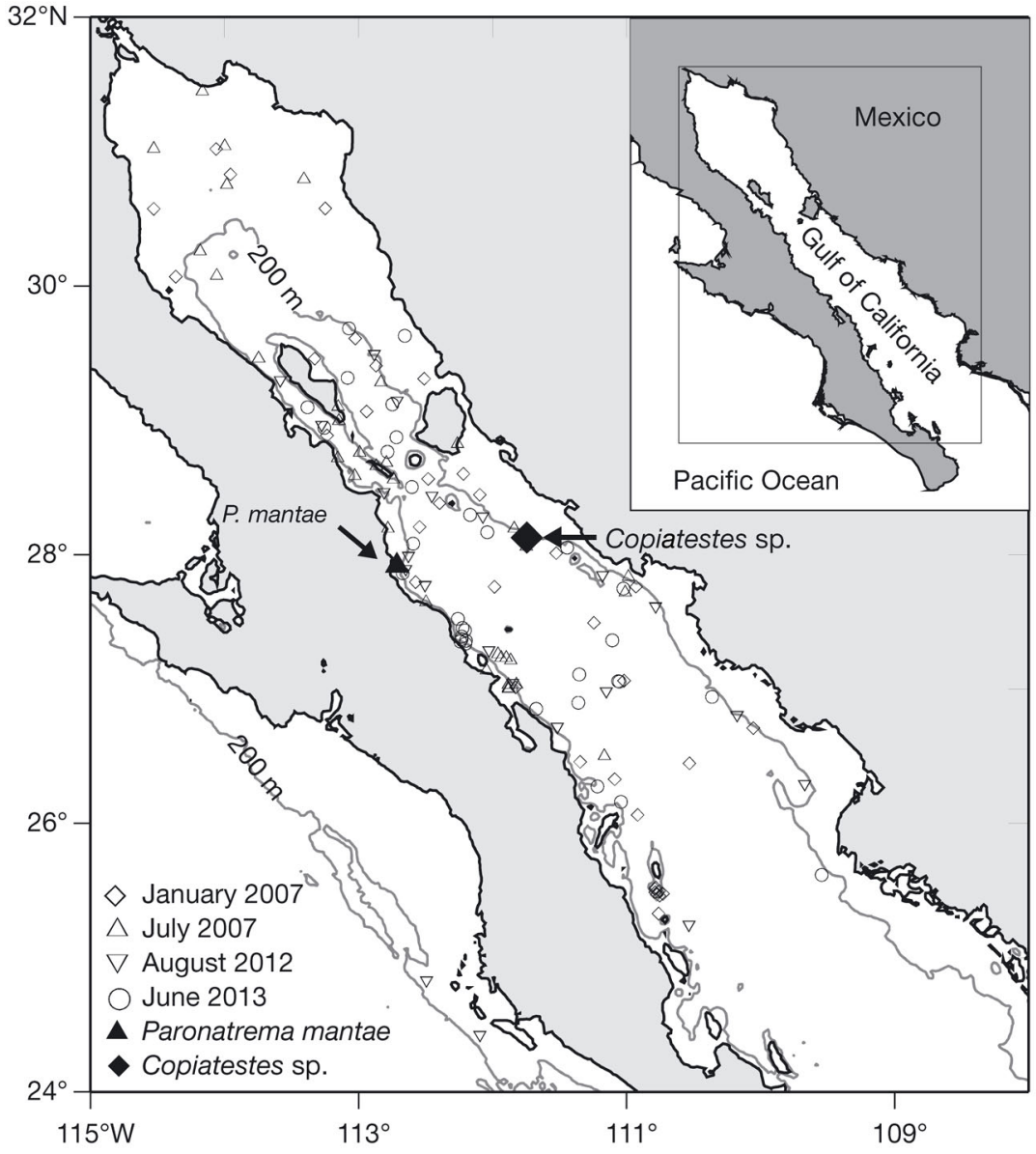

Fig. 1. Area of study. Open symbols indicate the location of the zooplankton samples collected during 4 oceanographic cruises (January and July 2007, August 2012, and June 2013) in the Gulf of California. Black symbols indicate the near-shore locations of krill parasitized by trematodes croscope (Axiostar, Carl Zeiss) equipped with a digital camera (Hyper HAD, Sony). The schematic drawings were made with a microscope equipped with a lucid camera. The morphological measurements were expressed in $\mu \mathrm{m}$ for trematodes and in $\mathrm{mm}$ for krill. Identification of trematode species was done using several taxonomic references (Manter 1940, Dollfus 1966, Overstreet 1970, Shimazu 1975, 2006, Curran \& Overstreet 2000, Gibson et al. 2002, Shvetsova 2004, Eduardo 2010).

\section{RESULTS}

We dissected 26751 Nyctiphanes simplex specimens and 5885 Nematoscelis difficilis specimens collected from 99 plankton samples. Only 3 trematode specimens belonging to 2 species of the family Syncoeliidae Looss, 1899 were detected parasitizing the krill. All of them showed morphology intermediate between cercaria and metacercaria (without tail) stages that we interpreted to be a mesocercaria stage (an unencysted larva with bifurcated tail and an incipient reproductive system). A trematode larva of Copiatestes sp. Crowcroft, 1948 was found parasitizing a juvenile female

The absolute prevalence is distinct from the relative prevalence estimate that counts the number of hosts parasitized with each parasite species divided by the number of host specimens examined in the sample expressed in percent (Bush et al. 1997). Because we examined all krill specimens collected in the samples, both methods provided the same percent value; however, it would be different if we had used subsamples.

\section{Identification of parasites}

Specimens of parasites were stained with Harris hematoxylin, dehydrated through a series of graded ethanol concentrations (70-96\%), cleared in methyl salicylate, and mounted in synthetic resin for permanent preparations. Observations of fixed and later stained specimens were viewed with an optical mi-
$N$. difficilis (8.1 $\mathrm{mm}$ total length) during winter (January 2007). Two specimens of Paronatrema mantae Manter, 1940 were found, with the forebody laterally bent, compressing the ventral sucker. One trematode was found parasitizing a juvenile $N$. simplex $(6.8 \mathrm{~mm}$ total length) from the Bongo net and another one was found parasitizing an adult $N$. simplex male $(10 \mathrm{~mm}$ total length) collected at the same station but with the non-quantitative zooplankton net during summer (July 2007). We did not find trematodes parasitizing krill in samples collected during August 2012 and June 2013 cruises at 44 oceanographic stations. In addition to these trematodes, we found other helminth species during the same cruises $(\mathrm{N}=530$ parasitizing $N$. simplex specimens), where Cestoda were the numerically dominant helminth endoparasites $(98.8 \%)$. Acanthocephala $(0.56 \%)$, Nematoda $(0.18 \%)$, and Trematoda $(0.37 \%)$ were present in considerably low proportions. This information provides a quantitative 
Table 1. Worldwide parasitic diversity of digenetic trematodes reported parasitizing krill (Order Euphausiacea). Larval stage given as 'reported (corrected)'; current taxonomy given where different from first column. Ad: adult; Juv: juvenile; Int.: intensity; Prev.: prevalence; $(-)$ not reported in original reference

\begin{tabular}{|c|c|c|}
\hline $\begin{array}{l}\text { Trematode } \\
\text { Species and authority }\end{array}$ & Larval stage & $\begin{array}{l}\text { Host } \\
\text { Species and authority }\end{array}$ \\
\hline \multicolumn{3}{|l|}{ Family unidentified } \\
\hline (Monogenea) & - & Euphausia pacifica Hansen, 1911 \\
\hline (Digenea) & - & Thysanoessa inermis (Krøyer, 1846) \\
\hline Unidentified & - & Euphausia sp. \\
\hline Unidentified & - & Thysanopoda tricuspidata Milne-Edwards, 1837 \\
\hline \multicolumn{3}{|l|}{ Lepocreadiidae } \\
\hline Opisthogonoporus spp. & - & Euphausia similis \\
\hline \multicolumn{3}{|l|}{ Opecoelidae } \\
\hline $\begin{array}{l}\text { Pseudopecoelus japonicus } \\
\quad \text { (Yamaguti, 1938) von Wicklen, } 1946\end{array}$ & Metacercaria (Metacercaria) & Euphausia similis \\
\hline Pseudopecoelus japonicus & - & Thysanopoda sp. \\
\hline $\begin{array}{l}\text { Neonotoporus trachuri } \\
\quad \text { (Yamaguti, 1938) Srivastava, } 1942\end{array}$ & Metacercaria (Metacercaria) & Euphausia similis \\
\hline Pseudopecoelus japonicus & Metacercaria (Metacercaria) & Euphausia similis \\
\hline \multicolumn{3}{|l|}{ Syncoeliidae } \\
\hline Distomum filiferum (Leukard in G.O. Sars, 1885) & Metacercaria (Mesocercaria) & Nematoscelis megalops G.O. Sars, 1883 \\
\hline Distomum filiferum & Metacercaria (Mesocercaria) & Thysanoessa gregaria G.O. Sars, 1883 \\
\hline Paronatrema sp. & Metacercaria (Metacercaria) & Nyctiphanes couchii (Bell, 1853) \\
\hline (Metacercaria theomonodi) (genus and species not valid) & (Metacercaria) & Nyctiphanes couchii \\
\hline (Metacercaria type B) & - & Euphausia similis G.O. Sars, 1885 \\
\hline Paronatrema spp. & Mesocercaria (Metacercaria) & Euphausia similis \\
\hline Paronatrema sp. (1) & Mesocercaria (Metacercaria) & Euphausia similis \\
\hline Paronatrema sp. & - & Euphausia similis \\
\hline Syncoelium sp. & Metacercaria (Mesocercaria) & Euphausia similis \\
\hline Syncoelium spp. & Metacercaria (Mesocercaria) & Euphausia similis \\
\hline Paronatrema sp. & (Metacercaria) & Euphausia diomedeae Ortmann, 1894 \\
\hline Distomum filiferum (Leukard in G.O. Sars, 1885) & $\begin{array}{l}\text { Metacercaria } \\
\text { (Mesocercaria-Metacercaria) }\end{array}$ & Nematoscelis megalops \\
\hline Paronatrema sp. & Metacercaria (Mesocercaria) & Euphausia pacifica \\
\hline Paronatrema spp. & Metacercaria (Mesocercaria) & Euphausia pacifica \\
\hline Syncoelium spp. & Metacercaria (Mesocercaria) & Euphausia pacifica \\
\hline Syncoelium thyrsitae & Metacercaria (Metacercaria) & Nematoscelis sp. \\
\hline Syncoelium spp. & Metacercaria (Metacercaria) & Nematoscelis sp. \\
\hline Syncoelium filferum & Metacercaria (Mesocercaria) & Euphausia diomedeae, E. recurva and T. gregaria \\
\hline Syncoelium filferum & Metacercaria (Mesocercaria) & Euphausia diomedeae, E. recurva, and T. gregaria \\
\hline Syncoelium filiferum & Metacercaria (Mesocercaria) & Euphausia diomedeae \\
\hline Syncoelium filiferum & Metacercaria (Mesocercaria) & Euphausia diomedeae \\
\hline Paronatrema sp. 1 & Metacercaria (Mesocercaria) & Euphausia diomedeae \\
\hline Syncoelium filiferum & Metacercaria (Mesocercaria) & Euphausia diomedeae \\
\hline Syncoelium ragazzii (Setti, 1897) & - & Euphausia diomedeae \\
\hline Paronatrema sp. A,B & Metacercaria (Mesocercaria) & Euphausia recurva Hansen, 1905 \\
\hline Syncoelium spp. & Metacercaria (Mesocercaria) & Euphausia vallentini Stebbing, 1900 \\
\hline Paronatrema sp. (2) & Metacercaria (Mesocercaria) & Not identified \\
\hline Copiatestes filiferus (Leuckart in G.O. Sars, 1885) Gibson \& Bray, 1977 & - & Euphausia diomedeae \\
\hline Syncoelium spp. & Metacercaria (Mesocercaria) & Euphausia similis \\
\hline Copiatestes filiferus & - & Nematoscelis megalops \\
\hline Copiatestes thyrsitae & (Metacercaria) & Nematoscelis sp. \\
\hline Copiatestes filiferus & - & Thysanoessa gregaria G.O. Sars, 1883 \\
\hline Paronatrema sp. & - & Nyctiphanes simplex Hansen, 1911 \\
\hline Copiatestes sp. & (Mesocercaria) & Nematoscelis difficilis Hansen, 1911 \\
\hline Paronatrema mantae Manter, 1940 & (Mesocercaria) & Nyctiphanes simplex \\
\hline
\end{tabular}

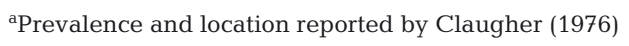


Table 1 (continued)

\begin{tabular}{cccl}
\multicolumn{3}{c}{ Infection } & Sampling region \\
Phase & Int. Prev. (\%) & \\
& & & \\
& & 0.003526 & East China Sea, $31.16^{\circ} \mathrm{N}, 126.52^{\circ}$ \\
- & - & 0.565 & East China Sea, $49^{\circ} 40^{\prime} \mathrm{N}, 151^{\circ} 11^{\prime}$ \\
- & - & - & Tropical western Pacific Ocean, \\
& & & $5^{\circ} \mathrm{N}-15^{\circ} \mathrm{S}, 160^{\circ} \mathrm{W}-180^{\circ} \mathrm{W}$ \\
- & - & - & Tropical western Pacific Ocean, \\
& & & $5^{\circ} \mathrm{N}-15^{\circ} \mathrm{S}, 160^{\circ} \mathrm{W}-180^{\circ} \mathrm{W}$
\end{tabular}

$$
\begin{array}{cccl}
- & - & - & \text { Suruga Bay, Japan } \\
\text { Juv-Ad } & - & 1.7-38.3 & \text { Suruga Bay, Japan } \\
- & - & - & \begin{array}{l}
\text { Russia } \\
-
\end{array} \\
- & - & - & \text { Suruga Bay, Japan }
\end{array}
$$

\begin{tabular}{|c|c|c|c|}
\hline Ad & $1-2$ & $90^{\mathrm{a}}$ & South Atlantic, $37^{\circ} 29^{\prime} \mathrm{S}, 27^{\circ} 31^{\prime} \mathrm{W}^{\mathrm{a}}$ \\
\hline Ad & $1-2$ & - & South Atlantic \\
\hline Ad & 1 & - & Mediterranean Sea \\
\hline Ad & - & - & Mediterranean Sea \\
\hline- & - & - & Suruga Bay, Japan \\
\hline- & - & 0.00004 & Tosa Bay, North Pacific \\
\hline- & - & 0.000005 & Suruga Bay, Japan \\
\hline - & - & - & Suruga Bay, Japan \\
\hline- & - & - & Suruga Bay, Japan \\
\hline- & - & 0.000030 & Suruga Bay, Japan \\
\hline- & 1 & - & $\begin{array}{l}\text { Tropical western Pacific Ocean, } \\
5^{\circ} \mathrm{N}-15^{\circ} \mathrm{S}, 160^{\circ} \mathrm{W}-180^{\circ} \mathrm{W}\end{array}$ \\
\hline Ad & $1-2$ & - & South Atlantic, $36^{\circ} 55^{\prime} \mathrm{S}, 12^{\circ} 12^{\prime} \mathrm{W}$ \\
\hline Ad & 1 & - & East China Sea, $31^{\circ} 16^{\prime} \mathrm{N}, 126^{\circ} 52^{\prime} \mathrm{E}$ \\
\hline Ad & 1 & 0.000035 & East China Sea, $31^{\circ} 16^{\prime} \mathrm{N}, 126^{\circ} 52^{\prime} \mathrm{E}$ \\
\hline- & - & 0.007 & No data \\
\hline- & 1 & 0.91 & North of Possession Island, $44^{\circ} 29^{\prime} \mathrm{S}, 55^{\circ} 58^{\prime} \mathrm{E}$ \\
\hline- & - & 0.45 & North of Possession Island, $44^{\circ} 29^{\prime} \mathrm{S}, 55^{\circ} 58^{\prime} \mathrm{E}$ \\
\hline- & - & 0.88 & Eastern New Caledonia, $24^{\circ} 49^{\prime} \mathrm{S}, 177^{\circ} 24^{\prime} \mathrm{E}$ \\
\hline- & - & 0.85 & Eastern New Caledonia, $24^{\circ} 49^{\prime} \mathrm{S}, 177^{\circ} 25^{\prime} \mathrm{E}$ \\
\hline- & - & 0.101 & Solomon Sea, $10^{\circ} 17^{\prime} \mathrm{S}, 157^{\circ} 56^{\prime} \mathrm{E}$ \\
\hline- & - & 0.056 & Solomon Sea, $10^{\circ} 17^{\prime} \mathrm{S}, 157^{\circ} 56^{\prime} \mathrm{E}$ \\
\hline- & - & 0.155 & Eastern New Caledonia, $25^{\circ} 15^{\prime} \mathrm{S}, 177^{\circ} 49^{\prime} \mathrm{E}$ \\
\hline- & - & 1.01 & $10^{\circ} 17^{\prime} \mathrm{S}, 157^{\circ} 56^{\prime} \mathrm{E}$ \\
\hline- & - & 0.056 & Eastern New Caledonia, $10^{\circ} 07^{\prime} \mathrm{S}, 157^{\circ} 51^{\prime} \mathrm{E}$ \\
\hline- & - & 0.012 & Eastern New Caledonia. $24^{\circ} 42^{\prime} \mathrm{S}, 177^{\circ} 17^{\prime} \mathrm{E}$ \\
\hline- & - & 0.009 & North of Port Aux Francais, $45^{\circ} 53^{\prime} \mathrm{S}, 65^{\circ} 08^{\prime} \mathrm{E}$ \\
\hline- & - & - & East China Sea \\
\hline- & - & - & Suruga Bay, Japan \\
\hline - & - & - & - \\
\hline - & - & - & - \\
\hline - & - & - & - \\
\hline- & - & - & - \\
\hline Ad & 1 & 0.0285 & Gulf of California, Mexico \\
\hline Juv & 1 & 0.16 & Gulf of California, Mexico, $28^{\circ} 08.47^{\prime} \mathrm{N}, 111^{\circ} 44.65^{\prime} \mathrm{W}$ \\
\hline Juv & 1 & 0.03 & Gulf of California, Mexico, $27^{\circ} 56.77^{\prime} \mathrm{N}, 112^{\circ} 42.86^{\prime} \mathrm{W}$ \\
\hline
\end{tabular}$$
\text { Juv-Ad } 1 \quad 0.08-1.28 \quad \text { Suruga Bay, Japan }
$$

Original

reference

Kagei (1974)

Kagei (1974)

Shimazu (1972)

Komaki (1970)

Reimer et al. (1971)

Shimazu (1972)

Shimazu (1982)

Sars (1885)

Sars (1885)

Dollfus (1937)

Dollfus (1966)

Komaki (1970)

Shimazu (1971)

Shimazu (1972)

Shimazu (1972)

Shimazu (1972)

Shimazu (1972)

Slankis \& Shevchenko (1974)

Claugher (1976)

Shimazu \& Kagei (1978)

Shimazu \& Kagei (1978)

Kagei (1979)

Kagei (1979)

Kagei (1979)

Kagei (1979)

Kagei (1979)

Kagei (1979)

Kagei (1979)

Kagei (1979)

Kagei (1979)

Kagei (1979), Shimazu (2006)

Kagei (1979)

Kagei (1979), Shimazu (2006)

Shimazu (1982)

Shimazu (2006)

Shimazu (2006)

Shimazu (2006)

Shimazu (2006)

Shimazu (2006)

Gómez-Gutiérrez et al. (2010)

Present study

Present study
Trematode current taxonomy (reference)
Slankis \& Shevchenko (1974)

Slankis \& Shevchenko (1974)

Paronatrema sp. (Shimazu \& Kagei 1978) 
perspective about the low frequency and relative abundance of trematodes that parasitize krill in the Gulf of California.

The 3 specimens of krill parasitized with trematodes had normal external appearance (without swollen cephalothorax or body deformation), and the parasites were discovered only after the cephalothorax was dissected. The parasitized $N$. simplex male had an extruded spermatophore but no evident gonad development in the cephalothorax. The $N$. difficilis juvenile female had an immature gonad (Stage I) and without spermatophore attached to the thelycum that would indicate recent reproductive activity.

\section{Paronatrema mantae Manter, 1940}

The 2 specimens of $P$. mantae (Fig. 2A-H) were detected in the mesocercaria stage, collected from 1 of 16 zooplankton samples collected in July 2007 $\left(27^{\circ} 56.77^{\prime} \mathrm{N}, 112^{\circ} 42.86^{\prime} \mathrm{W}\right)$. At this location, N. simplex had a total abundance of 4077 ind. $1000 \mathrm{~m}^{-3}$ and the trematodes had an abundance of 1.2 trematodes $1000 \mathrm{~m}^{-3}$, with an absolute station prevalence of $0.03 \%$. This is the first report of $P$. mantae in the larval phase; thus, we describe its morphology from one of our specimens available for further comparative morphological studies. P. mantae was $3160 \mu \mathrm{m}$ long and $800 \mu \mathrm{m}$ wide (just posterior to the acetabulum); body dorso-ventrally flattened; forebody narrow, $1550 \mu \mathrm{m}$ long; hindbody $1000 \mu \mathrm{m}$ long, with a bifurcated tail with granular appearance, $390 \mu \mathrm{m}$ long and $860 \mu \mathrm{m}$ wide (Fig. 2A). Oral sucker terminal, $450 \mu \mathrm{m}$ long and $520 \mu \mathrm{m}$ wide, with an internal ring armed with about 40 small accessory suckers. Ventral sucker $930 \mu \mathrm{m}$ long with 36 small accessory suckers, protruding $590 \mu \mathrm{m}$ on a muscular base; oral/ventral sucker with a length ratio of 1:2. Mouth without prepharynx, pharynx $240 \mu \mathrm{m}$ long and $130 \mu \mathrm{m}$ wide. Ceca bending anteriorly to mid-pharynx level (apparently a cecal pouch is present). It is not clear whether the sinuous intestinal cecum opens into the excretory vesicle. The uterus is well-developed in many narrow transverse coils filling most of hindbody (covering other organs) and extending to the near posterior end of the body; the genital pore is located opposite the pharynx. The general morphology of the adult stage of $P$. mantae is shown in Fig. $2 \mathrm{H}$ (obtained from Manter 1940). A comparison of the morphological and biometric measurements and proportions among the $P$. mantae mesocercaria (present study) and metacercaria larval stages (Dollfus 1966) and the adult stage (Manter 1940) is shown in Table 2.
Mesocercaria and metacercaria larval stages of Paronatrema described from krill bear slight differences between them and compared to adults. One of the most noticeable ontogenetic changes from larval stage to adult is the forebody:hindbody ratio. In larval stages, the forebody is larger than the hindbody, and this is reversed in the adult stage, suggesting an allometric growth pattern (Table 2).

\section{Remarks}

Dollfus (1966) reported the trematode Metacercaria teomondi as a parasite of Nyctiphanes couchii (Bell, 1853). Kagei (1974) reported a 'monogenean trematode' parasitizing Euphausia pacifica Hansen, 1911. Later, both specimens were referred to as Paronatrema spp. (Syncoeliidae) (Manter \& Pritchard pers. comm. in Dollfus 1966, Shimazu \& Kagei 1978). More recently, Gómez-Gutiérrez et al. (2010) reported 'Paronatrema-like metacercaria (Syncoeliidae)' parasitizing N. simplex in the Gulf of California. However, analyzing their published photographs, they actually showed photographs of a Eutetrarhynchidae cestode rather than a trematode (see their Figs. 5c,d). Paronatrema sp. parasitizing E. pacifica (Shimazu \& Kagei 1978) differs from our P. mantae specimen because their specimen has an oral sucker that lacks accessory suckers and has fewer accessory suckers $(n=26)$ on the acetabulum (Fig. 2D-G). Our tailed P. mantae mesocercaria had a total length (3160 $\mu \mathrm{m}$ long) similar to that of the untailed metacercaria specimen (1500-3000 $\mu \mathrm{m})$ reported by Dollfus (1966). However, the specimens described by Dollfus (1966) are slender, have a variable number of accessory suckers (sometimes absent), and have a relatively smaller ventral sucker (700 $\mu$ m diameter) than $P$. mantae (930 $\mu \mathrm{m}$ diameter). The type species in the adult stage of $P$. vaginicola Dollfus, 1937 and $P$. boholanum Eduardo, 2010 (larval stages unknown) have accessory suckers only in the ventral sucker (Table 2). The genus Paronatrema currently includes 3 extant species ( $P$. mantae, $P$. vaginicola, and $P$. boholanum) (World Register of Marine Species [WoRMS], www.marinespecies.org).

\section{Copiatestes sp. Crowcroft, 1948}

Copiatestes sp. was found in the mesocercaria stage, parasitizing $N$. difficilis at 1 of the 30 sampling stations in January 2007 ( $\left.28^{\circ} 08.47^{\prime} \mathrm{N}, 111^{\circ} 44.65^{\prime} \mathrm{W}\right)$. At this location, $N$. difficilis had an abundance of 

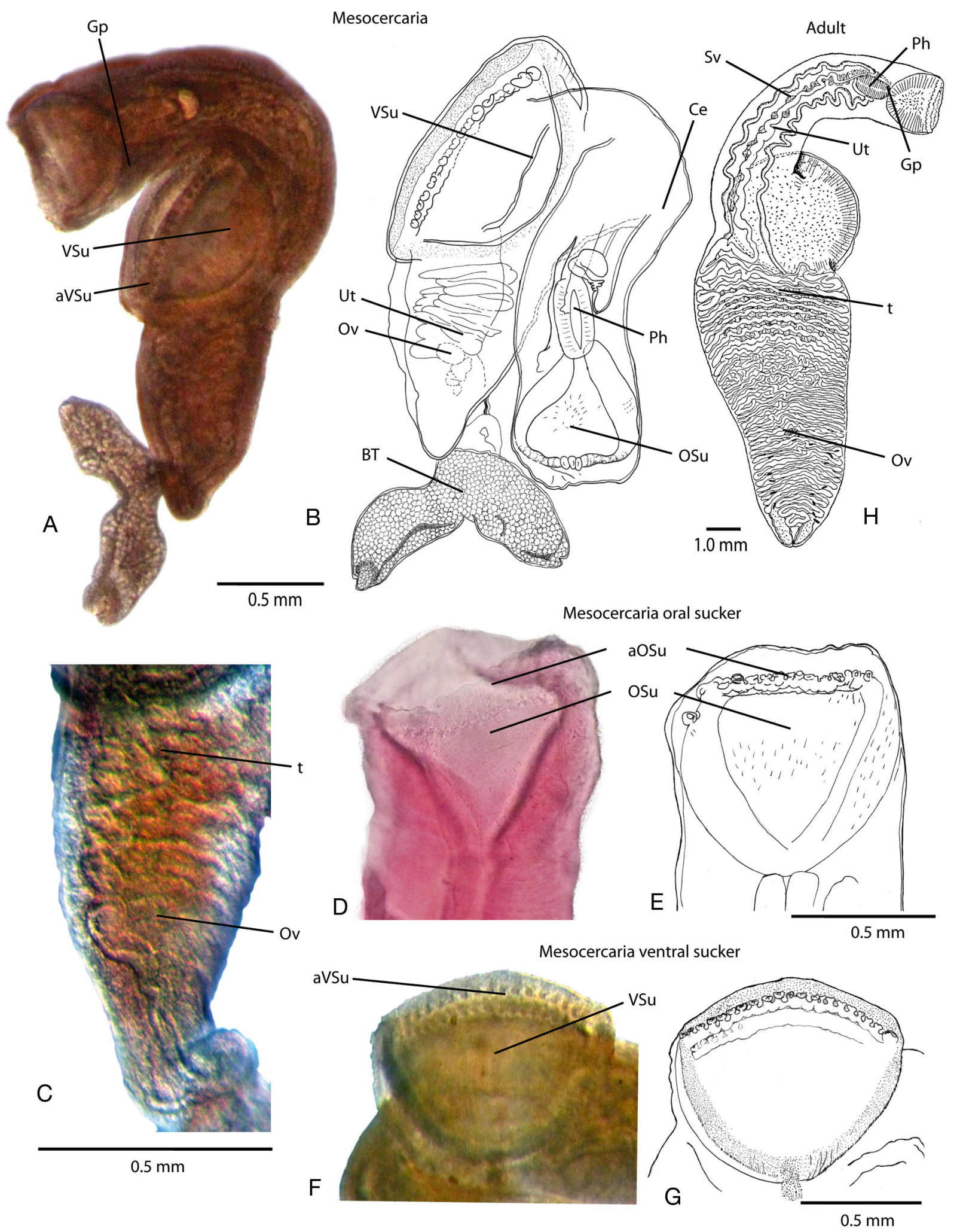

Fig. 2. Paronatrema mantae Manter 1940. (A-H) Trematode mesocercaria (unencysted) parasitizing the krill Nyctiphanes simplex in the Gulf of California. (A, $, D, F)$ Photograph with optical microscope and $(B, E, G)$ drawings of mesocercaria. Detail of (C) coiled uterus, $(\mathrm{D}, \mathrm{E})$ accessory suckers of oral sucker, $(\mathrm{F}, \mathrm{G})$ accessory suckers of acetabulum, and $(\mathrm{H})$ drawing of an adult taken from Manter (1940). VSu: ventral sucker; aVSu: accessory ventral sucker; OSu: oral sucker; Ce: ceca; Ph: pharynx; Ut: uterus; Ov: ovary; Gp: genital pore; Te: testes; Sv: seminal vesicle; BT: bifurcate tail 
Table 2. Comparison of Paronatrema mantae morphological and biometrical measurements and proportions among larvalstage mesocercariae (with tail, present study), metacercariae (no tail), and adults (Manter 1940). TL: total length; BW: body width; Os: oral sucker; Vs: ventral sucker; Pp: prepharynx; PL: pharynx length; PW: pharynx width; Fb: forebody; Hb; hindbody

\begin{tabular}{|c|c|c|c|c|c|c|c|c|c|}
\hline $\begin{array}{l}\text { Species } \\
\text { Stage (n) } \\
\text { (Reference) }\end{array}$ & $\begin{array}{c}\mathrm{TL} \\
(\mu \mathrm{m})\end{array}$ & $\begin{array}{c}- \text { Body } \\
\text { BW } \\
(\mu \mathrm{m})\end{array}$ & TL:BW & $\begin{array}{c}\text { Os } \\
(\mu \mathrm{m})\end{array}$ & $\begin{array}{l}\text { Suckers } \\
\text { Vs } \\
(\mu \mathrm{m})\end{array}$ & Os:Vs & $\mathrm{Pp}$ & $\begin{array}{l}\text { Pharynx- } \\
\text { PL } \\
(\mu \mathrm{m})\end{array}$ & $\begin{array}{l}\text { PW } \\
(\mu \mathrm{m})\end{array}$ \\
\hline $\begin{array}{l}\text { Paronatrema sp. } \\
\text { Mesocercaria }(\mathrm{n}=1) \\
\text { (Shimazu \& Kagei 1978) }\end{array}$ & 3710 & 730 & $5.1: 1$ & 430 & 950 & $1: 2$ & Absent & 240 & 210 \\
\hline $\begin{array}{l}\text { P. mantae } \\
\text { Mesocercaria }(\mathrm{n}=1) \\
\text { (Present study) }\end{array}$ & 3160 & 800 & $4.0: 1^{\mathrm{a}}$ & 450 & 930 & $1: 2^{\mathrm{a}}$ & Absent $^{\mathrm{a}}$ & 240 & 130 \\
\hline $\begin{array}{l}\text { Paronatrema sp. } \\
\text { Metacercaria }(\mathrm{n}=12) \\
\text { (Dollfus 1966) }\end{array}$ & 3000 & 1000 & $3: 1$ & 190 & 700 & $1: 3.6$ & Absent & 111 & 85 \\
\hline $\begin{array}{l}P . \text { vaginicola } \\
\text { Adult }(\mathrm{n}=7) \\
\text { (Dollfus 1937) }\end{array}$ & $\begin{array}{l}8000- \\
20500\end{array}$ & $\begin{array}{c}2000- \\
3500\end{array}$ & $4.0-5.9: 1$ & $\begin{array}{l}932- \\
1179\end{array}$ & $\begin{array}{c}1824- \\
2807\end{array}$ & $1: 1.7-2.1$ & Absent & $\begin{array}{c}494- \\
870\end{array}$ & $\begin{array}{c}371- \\
477\end{array}$ \\
\hline $\begin{array}{l}\text { P. mantae } \\
\text { Adult }(\mathrm{n}=3) \\
\text { (Manter 1940) }\end{array}$ & 17500 & $\begin{array}{c}4180- \\
4610\end{array}$ & $3.8-4.2: 1$ & $\begin{array}{c}1809- \\
1971\end{array}$ & $\begin{array}{c}3064- \\
3591\end{array}$ & $1: 2^{\mathrm{a}}$ & Absent $^{\mathrm{a}}$ & $\begin{array}{c}1147- \\
1200\end{array}$ & $\begin{array}{c}634- \\
815\end{array}$ \\
\hline $\begin{array}{l}\text { P. boholanum } \\
\text { Adult }(\mathrm{n}=20) \\
(\text { Eduardo } 2010)\end{array}$ & 6349 & $\begin{array}{c}1725- \\
6125\end{array}$ & $\begin{array}{l}1.0- \\
3.7: 1\end{array}$ & $\begin{array}{c}437- \\
625\end{array}$ & $\begin{array}{c}1050- \\
3950\end{array}$ & $\begin{array}{c}1: 3.3- \\
4.8\end{array}$ & Absent & $\begin{array}{c}390- \\
570\end{array}$ & $\begin{array}{c}200- \\
400\end{array}$ \\
\hline
\end{tabular}

745 ind. $1000 \mathrm{~m}^{-3}$, and the abundance of the trematode was 1.2 ind. $1000 \mathrm{~m}^{-3}$, with an absolute prevalence of $0.16 \%$.

We describe the larval morphology for further comparative studies. Body cylindrical and elongated; $2970 \mu \mathrm{m}$ long and $360 \mu \mathrm{m}$ wide (at mid-posterior body); cuticle smooth and thick (difficult to observe internal organs); forebody $1490 \mu \mathrm{m}$ long (about 50\% of the total body length), with small papillae easily detected at pharynx that spreads out from the oral sucker to the acetabulum; hindbody $1140 \mu \mathrm{m}$ long; bifurcated tail located at the posterior part of the body, $300 \mu \mathrm{m}$ long and $820 \mu \mathrm{m}$ wide. Oral sucker and acetabulum without accessory suckers; oral sucker $330 \mu \mathrm{m}$ long and $390 \mu \mathrm{m}$ wide; acetabulum $560 \mu \mathrm{m}$ long and $360 \mu \mathrm{m}$ wide; acetabulum with a stalk $170 \mu \mathrm{m}$ long, located near the middle part of the body and with extrinsic well-developed musculature; oral/ ventral sucker length ratio 1:1.6. Mouth without prepharynx; pharynx located immediately behind the oral sucker, $120 \mu \mathrm{m}$ long and $100 \mu \mathrm{m}$ wide; esophagus extremely short and divides almost immediately into 2 ceca that follow a sinuous shape to the area of the ventral sucker, where they diverge toward the sides of the hindbody; $>35$ oval testes $(23 \mu \mathrm{m}$ mean diame- ter) aligned roughly along 5 rows; small projecting genital papilla in a posterior-lateral position of the oral sucker (Fig. 3), seminal vesicle showed a sinuous shape to a point near the pharynx where it joins with the uterus to form a common genital sinus opening at the tip of the small genital papilla; ovary $60 \mu \mathrm{m}$ long located posterior from the testes in the first third of the hindbody (600 $\mu \mathrm{m}$ from the proximal tail).

\section{Remarks}

The first known digenetic trematode Distomum filiferum parasitizing Nematoscelis megalops G.O. Sars, 1883 and Thysanoessa gregaria G.O. Sars, 1883 reported by Sars (1885) (= Copiatestes filiferus (Leuckart in G.O. Sars, 1885) Gibson \& Bray, 1977 was recognized as junior synonyms of the monotypic genus Copiatestes thyrsitae Crowcroft, 1948 (Shvetsova 2004). However, we cautiously did not assign it to this species because our specimen had slight morphological differences that cannot be easily attributed to ontogenetic or interspecific features: (1) a well-developed bifurcated tail, (2) no long filaments located at the extreme of the hindbody (shown 
Table 2 (continued)

\begin{tabular}{|c|c|c|c|c|c|c|c|c|c|}
\hline Os:PL & $\begin{array}{l}\text { Cecal } \\
\text { pouch }\end{array}$ & $\begin{array}{l}\text { No. of } \\
\text { sucke } \\
\text { Os }\end{array}$ & $\begin{array}{l}\text { cessory } \\
\text { at: } \\
\quad \text { Vs }\end{array}$ & $\begin{array}{c}\mathrm{Fb} \\
(\mu \mathrm{m})\end{array}$ & $\begin{array}{l}\mathrm{Hb} \\
(\mu \mathrm{m})\end{array}$ & $\mathrm{Fb}: \mathrm{Hb}^{\mathrm{a}}$ & $\begin{array}{c}\text { Ovary } \\
\text { position }\end{array}$ & Tail & $\begin{array}{l}\text { Genital } \\
\text { pore } \\
\text { position }\end{array}$ \\
\hline $1: 0.55$ & Present $^{b}$ & Absent & 26 & 1550 & 1500 & $1.3: 1$ & $\begin{array}{l}\text { Near } \\
\text { middle } \\
\text { of Hb }\end{array}$ & Present & $\begin{array}{c}\text { Anterior, } \\
\text { bordering } \\
\text { pharynx }\end{array}$ \\
\hline $1: 0.53^{\mathrm{a}}$ & Present $^{a}$ & $\sim 40^{\mathrm{a}}$ & $36^{\mathrm{a}}$ & 1558 & 1006 & $1.5: 1$ & $\begin{array}{c}\sim^{1 / 3} \text { TL from } \\
\text { anterior } \\
\text { end }^{\mathrm{a}}\end{array}$ & Present & $\begin{array}{l}\text { Anterior, } \\
\text { opposite } \\
\text { pharynx }\end{array}$ \\
\hline $1: 0.58$ & Present ${ }^{b}$ & Present & Present & 2000 & 1000 & $2: 1$ & $\begin{array}{c}\sim 1 / 3 \mathrm{TL} \\
\text { from anterior } \\
\text { end }\end{array}$ & & $\begin{array}{l}\text { Anterior, } \\
\text { opposite } \\
\text { pharynx }\end{array}$ \\
\hline $\begin{array}{c}1: 0.41- \\
0.73\end{array}$ & & Absent & $35-38$ & $\begin{array}{c}3004- \\
6512\end{array}$ & $\begin{array}{c}4800- \\
6961\end{array}$ & $0.4-1.3: 1$ & $\begin{array}{l}\text { Ventral } \\
\text { portion } \\
\text { of } \mathrm{Hb}\end{array}$ & & $\begin{array}{l}\text { Anterior } \\
\text { to } \\
\text { pharynx }\end{array}$ \\
\hline $\begin{array}{c}1: 0.6- \\
0.66^{\mathrm{a}}\end{array}$ & Present $^{\mathrm{a}}$ & $41-47^{a}$ & $29-37^{a}$ & $\begin{array}{c}6680- \\
7000\end{array}$ & $\begin{array}{c}6300- \\
8400\end{array}$ & 1.1:1 & $\begin{array}{c}\sim 1 / 3 \mathrm{TL} \\
\text { from anterior } \\
\mathrm{end}^{\mathrm{a}}\end{array}$ & & $\begin{array}{l}\text { Anterior, } \\
\text { opposite } \\
\text { pharynx }\end{array}$ \\
\hline $\begin{array}{c}1: 0.62- \\
0.91\end{array}$ & & Absent & Present & 2500 & 3000 & $0.8: 1$ & $\begin{array}{l}\sim 1 / 4 \mathrm{TL} \\
\text { from posterior } \\
\text { end }\end{array}$ & & $\begin{array}{c}\text { Ventral, } \\
\text { level with } \\
\text { pharynx }\end{array}$ \\
\hline
\end{tabular}

in Sars 1885 and Claugher 1976), (3) a lobulated ovary located in the last third of the hindbody (in other Copiatestes descriptions, it is located in the middle part of the hindbody), and (4) arguably, the considerably high number of testes (up to 35) in the specimen collected in the Gulf of California while other specimens had only 11-18 testes. Because we have only 1 available specimen, we cannot conclude anything about intraspecific variability of such taxonomic characters. Therefore, we cannot determine whether our single specimen is a new species or whether it can be identified, without doubt, as $C$. thyrsitae. However, Gibson (2015), contrary to the point of view of Shvetsova (2004), reported in WoRMS (www.marinespecies.org) that the genus Copiatestes is not monotypic and includes 2 extant species: C. thyrsitae and C. filiferus.

\section{Worldwide records of trematodes infecting krill}

Assembling all published information highlights the enormous taxonomic problem posed by the originally reported 8 genera (10 species) and multiple unidentified trematode specimens. If synonymy of
Copiatestes species is valid (see Shvetsova 2004), the number of taxa infecting krill would decrease considerably. C. thyrsitae, P. mantae, and P. japonicus are the most frequent digenetic trematodes parasitizing krill (Table 1). This implies that these species should have broader zoogeographic patterns than previously thought and low specificity infecting different krill species (Table 1). Although our samples came from cruises collecting quantitative data, the prevalences were remarkably similar to previous reports involving non-quantitative trawls (Table 1).

\section{DISCUSSION}

Most investigations of trematodes parasitizing krill have been carried out from accidental findings or from non-quantitative sampling trawls (Table 1). This situation prevents estimating abundance of parasites and host populations that could lead to better understanding of the role of krill in the syncoeliid trematode life cycle. We estimated considerably low trematode population abundances (<1.2 ind. $\left.1000 \mathrm{~m}^{-3}\right)$ and prevalences $(0.03$ and $0.16 \%$ ) from quantitative zooplankton sampling. Comparing occurrence 
(our observations, $0.37 \%$ ) and prevalence of trematodes worldwide (Table 1), and those detected for other helminths in the Gulf of California (Cestoda [>98.8\%], Acanthocephala [0.56\%], and Nematoda $[0.18 \%$ ]; with $\mathrm{n}=530$ parasitizing Nyctiphanes simplex specimens from the same cruises (J. R. MoralesÁvila et al. unpubl. data) quantitatively confirms that $N$. simplex and Nematoscelis difficilis are not conspicuous intermediate hosts for these trematodes. This is partly explained by the low host specificity known for syncoeliid trematodes that frequently infect more than one secondary intermediate host species in their complex life cycle (Slankis \& Shevchenko 1974). This has been observed in other regions, where digenetic trematodes parasitize krill with low prevalences $(<1 \%)$ and typically with an intensity of 1 , rarely 2 (Table 1 ). For example, Euphausia similis shows very low prevalence $(0.00004 \%)$ at Tosa Bay, Japan (Shimazu 1971, 1982). There are only 2 reports of trematodes infecting krill at relatively high densities and prevalences (Table 1): Pseudopecoelus japonicus parasitizes E. similis G.O. Sars, 1883 with a prevalence of up to $38 \%$ at Suruga, Japan (Komaki 1970), and from the re-examination of the specimens from the Challenger Expedition 1872-1876, Claugher (1976) reported the highest $(90 \%)$ digenetic trematode (Copiatestes thyrsitae) prevalence documented so far in krill (120 specimens of Nematoscelis megalops), from the South Atlantic. From summarized information in Table 1 emerged a pattern that trematodes have distinct infection success and spreading strategies in different krill species and even in the same species in different areas. Most importantly, the diversity of trematodes infecting krill is not as high as previously thought (based on the synonymies), and these trematode species may have broad zoogeographic patterns infecting different krill species (low specificity). Our study is the first report of an endoparasite of $N$. difficilis (Table 1), which was previously known to be infected only with epibionts, ectoparasites, and mesoparasites (Field 1969, De Silva-Dávila et al. 2004, Landers et al. 2006, GómezGutiérrez et al. 2010).

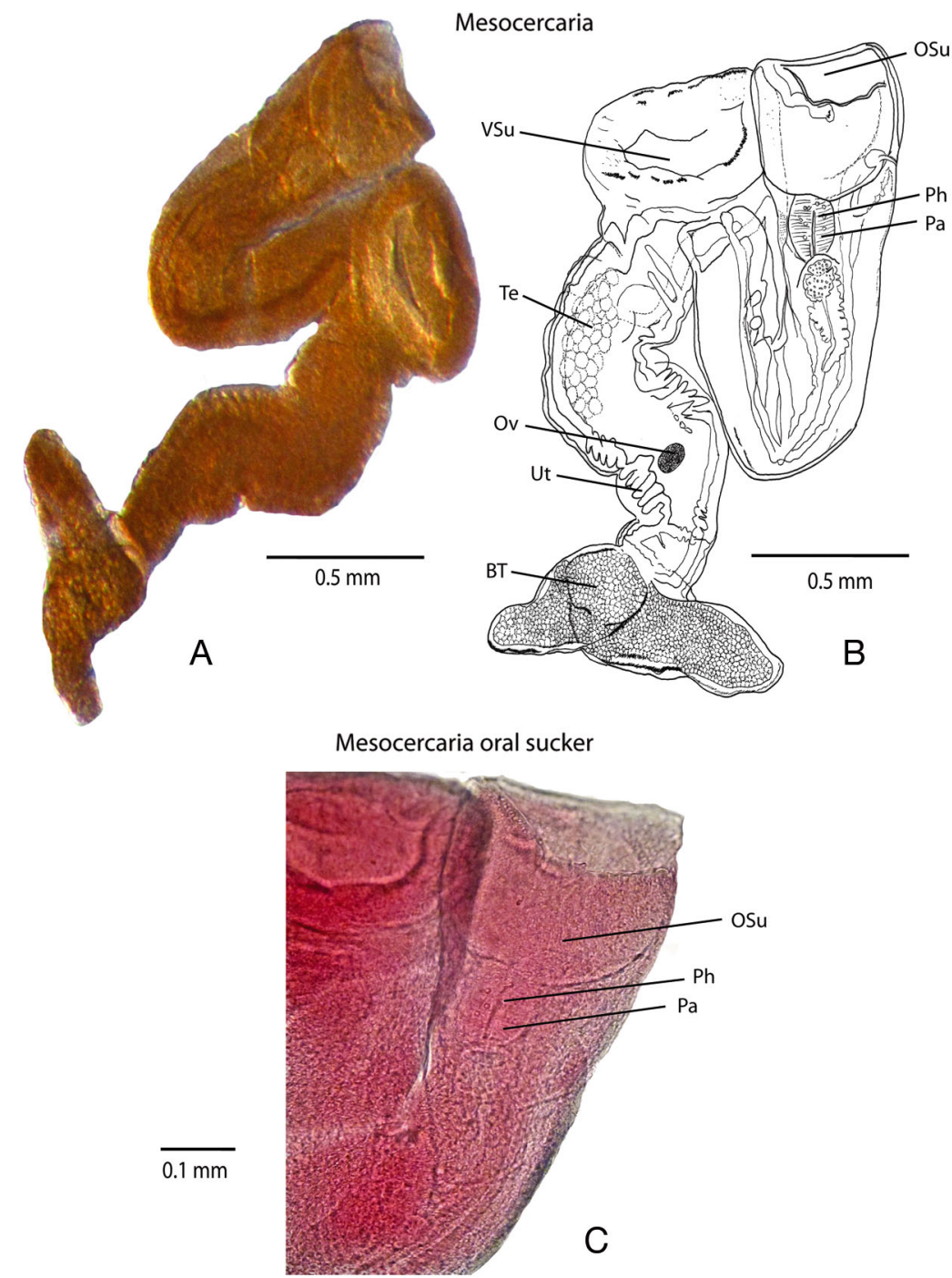

Fig. 3. Copiatestes sp. Crowcroft 1947. Trematode mesocercaria (unencysted) parasitizing the krill Nematoscelis difficilis in the Gulf of California. (A) Photograph with optical microscope, (B) drawing of mesocercaria, and (C) oral sucker. VSu: ventral sucker; OSu: oral sucker; Ce: ceca; Pa: papilla; Ph: pharynx; Te: testes; Ut: uterus; BT: bifurcate tail

\section{Syncoeliidae life cycle}

The life cycle of syncoeliid species is partly known, but nothing is known about the egg-cercaria stages of syncoeliid parasites, nor their first intermediate hosts (Gibson \& Bray 1977), although copepods and krill are considered their second intermediary hosts (Overstreet 1970, Marcogliese 1995, Busch et al. 2012). Syncoeliid trematodes show low host specificity because they have been previously found as: (1) mesocercaria stage in the krill hemocoel (unencysted with tail, present study), (2) free-living metacercariae (without host) (Odhner 1911, Dollfus 1966, Shimazu 1982, 2006), (3) metacercariae externally attached on 
zooplankton (trematodes without tail), such as on Nyctiphanes couchii (Dollfus 1966), and copepods (Overstreet 1970, Schell 1985), and (4) metacercaria stage in krill hemocoel (presumably with tail) (Kagei 1979). Syncoeliid trematodes are most frequently observed as non-encysted tailed larvae (inappropriately named 'unencysted metacercariae,' but we think it is actually a mesocercaria stage with immature reproductive organs, defined as an intermediate form between cercaria and metacercaria; Galaktionov \& Dobrovolskij 2003) occurring in the hemocoel of N. megalops and Thysanoessa gregaria (Sars 1885, Claugher 1976), E. pacifica (Shimazu \& Kagei 1978, Shimazu 2006), and N. simplex and N. difficilis (present study). In nektonic final hosts, syncoeliids are found attached to skin, and buccal and gill cavities of teleosteans (Shvetsova 2004), zooplanktophagous Chondrichthyes fish (Manta birostris (Walbaum, 1792) and Rhincodon typus Smith, 1828 parasitized by Paronatrema mantae and P. boholanum; Dyer et al. 1988, Villareal \& Dailey 1993, Curran \& Overstreet 2000, Eduardo 2010), and carnivorous shark species (Prionace glauca (Linnaeus, 1758) parasitized by $P$. vaginicola; Curran \& Overstreet 2000), and syncoellid tramatodes were reported attached to the legs of seabirds (Claugher 1976). Because trematodes have been detected inside krill hemocoel as mesocercariae (unencysted with tail) and metacercariae (Claugher 1976, Kagei 1979), we propose that trematodes can develop in this kind of host; thus, krill should be considered an intermediate host rather than a paratenic or an accidental host (Table 1).

The neritic krill $N$. simplex migrates and forms dense swarms close the seafloor (unlikely for $N$. difficilis because this is an oceanic species; Robinson \& Gómez-Gutiérrez 1998, Gómez-Gutiérrez \& Robinson 2006). This transient epibenthic N. simplex behavior may facilitate transmission of parasites from benthic to nektonic prey and predators in the pelagic habitat. Future studies may determine whether syncoeliid trematodes actively search for the next host or passively infect krill and their predators through trophic prey-predator interactions.

\section{CONCLUSIONS}

This is the first confirmed record of trematodes infecting krill in the Gulf of California. The occurrence of Paronatrema infecting Nyctiphanes simplex represents the first record of $P$. mantae in the larval phase (mesocercaria) parasitizing a zooplankton host. Additionally, Copiatestes trematodes infecting Nemato- scelis difficilis is the first known endoparasite recorded in this species. Although these 2 numerically dominant krill species tend to form relatively dense aggregations available to predators and parasites, we present quantitative evidence that trematodes in the Gulf of California typically have considerably low population abundance and low prevalences. From a worldwide review of the literature on trematodes parasitizing krill emerges the perspective that syncoeliid trematodes also have (with few exceptions) low population densities and prevalences and lower species diversities than previously thought (suggesting a broader zoogeographic distribution range of these parasites). The finding of syncoeliid trematodes as mesocercariae (a transitional developmental stage between cercaria and metacercariae stages) inside the host suggests that krill species in the Gulf of California function as intermediate hosts.

Acknowledgements. We thank the crew of the RV 'El Puma' and graduate students and researchers at the Fisheries Ecology Laboratory of ICMyL-UNAM, UABCS, and CICIMARIPN for their assistance with zooplankton sampling. Funding was provided by the Centro Interdisciplinario de Ciencias Marinas-IPN (SIP 2007-2015), CONACYT-FOSEMARNAT (2004-C01-144), CONACYT-SAGARPA (2005-1-11717), CON ACYT Ciencia Básica (2012-178615-C01), and Instituto de Ciencias del Mar y Limnología of the Universidad Nacional Autónoma de México (PAPIIT-UNAM grant IN20066610-3 and CONACYT Ciencia Básica 2010-152850-C01). J.R.M.A. was a recipient of a CONACYT (176164) and BEIFI-IPN (2010-152580-C01 and 178615) doctoral grants. J.G.G. is an EDI-IPN and COFAA-IPN fellow.

\section{LITERATURE CITED}

Baker A de C, Boden P, Brinton E (1990) A practical guide to the euphausiids of the world. Natural History Museum Publications, London

Brinton E (1981) Euphausiid distributions in the California Current during the warm winter spring of 1977-78, in the context of a 1949-1966 time series. Calif Coop Ocean Fish Invest Rep 22:135-154

Brinton E, Townsend AW (1980) Euphausiids in the Gulf of California - the 1957 cruises. Calif Coop Ocean Fish Invest Rep 21:211-236

Brinton E, Ohman MD, Townsend AW, Knight MD, Bridgeman AL (2000) Euphausiids of the world ocean. World Biodiversity Database CD-ROM Series for [Microsoft] Windows version 1.0. Expert Center for Taxonomic Identification, Amsterdam

Busch MW, Kuhn T, Julian M, Klimpel S (2012) Marine crustaceans as potential hosts and vectors for metazoan parasites. In: Mehlhorn $\mathrm{H}$ (ed) Arthropods as vectors of emerging diseases, $3^{\text {rd }}$ edn. Springer, Berlin, p 329-360

Bush AO, Lafferty KD, Lotz JM, Shostak AW (1997) Parasitology meets ecology on its own terms: Margolis et al. revisited. J Parasitol 83:575-583 
Claugher D (1976) A trematode associated with the death of the white-faced storm petrel (Pelagodroma marina) on the Chatham Islands. J Nat Hist 10:633-641

Curran SS, Overstreet RM (2000) Syncoelium vermilionensis sp. n., (Hemiuroidea: Syncoeliidae) and new records for members of Azygiidae, Ptychogonimidae, and Syncoeliidae parasitizing Elasmobranchs in the Gulf of California. In: Salgado-Maldonado, García Aldrete AN, VidalMartínez VM (eds) Metazoan parasites in the neotropics: a systematic and ecological perspective. Instituto de Biología, Universidad Nacional Automoma de México, Mexico City, p 117-133

De Silva-Dávila R, Palomares-García R, González-Rodríguez E, Maldonado-López V (2004) Varamiento de Nematoscelis difficilis en la Bahía de La Paz, Baja California Sur, México. In: Hendrickx ME (ed) Contributions to the study of East Pacific crustaceans 3. Universidad Nacional Autónoma de México, Mexico City, p 89-97

Dollfus RP (1937) Les trématodes digenea des Selaciens (Plagiostomes) Catalogue par hôtes. Distribution géographique. Ann Parasitol 15:259-281 (in French)

Dollfus RP (1966) Métacercaire énigmatique de distome du plancton de surface des îles du Cap Vert. Bull Mus Natl Hist Nat 38:195-200 (in French)

> Dyer WG, Williams EH, Williams LB (1988) Digenetic trematodes of marine fishes of Okinawa, Japan. J Parasitol 74: 638-645

Eduardo SL (2010) A new species of parasitic fluke, Paronatrema boholana Eduardo (Trematoda: Syncoeliidae) from the whale shark, Rhincodon typus Smith, 1828 (Orectolobiformes: Rhincodontidae) off Bohol Island, Philippines. Asia Life Sci 19:315-323

> Field LH (1969) The biology of Notophryxus lateralis (Isopoda: Epicaridea), parasitic on the euphausiid Nematoscelis difficilis. J Parasitol 55:1271-1277

Galaktionov KV, Dobrovolskij A (2003) The biology and evolution of trematodes: an essay on the biology, morphology, life cycles, transmissions, and evolution of digenetic trematodes. Springer Science \& Business Media, Dordrecht

Gendron D (1992) Population structure of daytime surface swarms of Nyctiphanes simplex (Crustacea: Euphausiacea) in the Gulf of California, Mexico. Mar Ecol Prog Ser 87:1-6

Gibson D (2015) Copiatestes Crowcroft, 1948. Available at www.marinespecies.org/aphia.php?p=taxdetails\&id= 108777 (accessed on 31 March 2015)

Gibson DI, Bray RA (1977) The Azygiidae, Hirudnellidae, Ptychogonimidae, Sclerodistimidae and Syncoeliidae (Digenea) of fishes from the Northeast Atlantic. Bull Br Mus (Nat Hist) Zool 32:167-245

Gibson DI, Jones A, Bray RA (2002) Keys to the Trematoda, Vol 1. CAB International and Natural History Museum, London

> Gómez-Gutiérrez J, Robinson CJ (2006) Tidal current transport of epibenthic swarms of the euphausiid Nyctiphanes simplex in a shallow, subtropical bay on Baja California peninsula, México. Mar Ecol Prog Ser 320:215-231

Gómez-Gutiérrez J, Robinson CJ, Kawaguchi S, Nicol S (2010) Parasite diversity of Nyctiphanes simplex and Nematoscelis difficilis (Crustacea: Euphausiacea) along the northwestern coast of Mexico. Dis Aquat Org 88: 249-266

Gómez-Gutiérrez J, Martínez-Gómez S, Robinson CJ (2012a) Seasonal growth, molt, and egg production rates of Nyctiphanes simplex (Crustacea: Euphausiacea) juveniles and adults in the Gulf of California. Mar Ecol Prog Ser 455:173-194

Gómez-Gutiérrez J, Strüder-Kypke MC, Lynn DH, Shaw TC and others (2012b) Pseudocollinia brintoni gen. nov., sp. nov. (Apostomatida: Colliniidae), a parasitoid ciliate infecting the euphausiid Nyctiphanes simplex. Dis Aquat Org 99:57-78

> González-Solís D, Castellanos-Osorio I, Beveridge I (2013) Larval trypanorhynch (Cestoda) infecting Euphausia americana (Euphausiacea) collected in the Mexican Caribbean Sea. Rev Mex Biodivers 84:664-667

Gregori M, Aznar FJ, Abollo E, Roura Á, González ÁF, Pascual S (2012) Nyctiphanes couchii as intermediate host for the acanthocephalan Bolbosoma balaenae in temperate waters of the NE Atlantic. Dis Aquat Org 99: $37-47$

> Gregori M, Aznar FJ, Abollo E, Roura Á, González ÁF, Pascual S (2013) Nyctiphanes couchii as intermediate host for Rhadinorhynchus sp. (Acanthocephala, Echinorhynchidae) from NW Iberian Peninsula waters. Dis Aquat Org 105:9-20

Kagei N (1974) Studies on anisakid Nematoda (Aniskinae) (IV). Survey of Anisakis larvae in the marine Crustacea. Koshu Eisei In Kenkyu Hokoku 23:65-71 (in Japanese with English summary)

Kagei N (1979) Euphausiids and their parasites (I). Geiken Tsushin 328:53-62 (in Japanese)

Kanaeva IP, Pavlov VY (1976) Nekotorye voprosy biologii Nyctiphanes simplex Hansen. [Some aspects of the biology of Nyctiphanes simplex Hansen]. In: Nejman AA (ed) Makroplankton morej i okeanov [Macroplankton of seas and oceans], Vol 110. Pishchevaya Promyshlennost, Moscow, p 90-94 (in Russian)

> Komaki Y (1970) On the parasitic organisms in a krill, Euphausia similis, from Suruga Bay. J Oceanogr Soc Jpn 26:283-295

> Landers SC, Gómez-Gutiérrez J, Peterson WT (2006) Gymnodinioides pacifica, n. sp., an exuviotrophic ciliated protozoan (Ciliophora, Apostomatida) from euphausiids of the Northeastern Pacific. Eur J Protistol 42:97-106

Lavaniegos-Espejo BE, Lara-Lara JR, Brinton E (1989) Effect of the 1982-83 El Niño event on the euphausiid populations of the Gulf of California. Calif Coop Ocean Fish Invest Rep 30:73-87

Manter HW (1940) Digenetic trematodes of fishes from the Galapagos Islands and the neighboring Pacific. Allan Hancock Pac Exped 2:325-479

Marcogliese DJ (1995) The role of zooplankton in the transmission of helminth parasites to fish. Rev Fish Biol Fish 5: 336-371

Notarbartolo-di-Sciara G (1988) Natural history of the rays of the genus Mobula in the Gulf of California. Fish Bull 86:45-66

Odhner T (1911) Zum natürlichen System der digenen Trematoden IV. Zool Anz 38:513-531 (in German)

Overstreet RM (1970) A syncoeliid (Hemiuroidea Faust, 1929) metacercaria on a copepod from the Atlantic Equatorial Current. J Parasitol 56:834-836

Reimer LW, Berger C, Heuer B, Lainka H, Rosenthal I, Scharnweber I (1971) On the distribution of larvae of helminths in plankton animals of the North Sea. Parazitilogiya 5:542-550 (in Russian with English summary)

Robinson CJ, Gómez-Gutiérrez J (1998) Daily vertical 
migration of dense deep scattering layers related to the shelf-break area along the northwest coast of Baja California, Mexico. J Plankton Res 20:1679-1697

Sampson L, Galván-Magaña F, De Silva-Dávila R, Aguíñiga-García S, O'Sullivan JB (2010) Diet and trophic position of the devil rays Mobula thurstoni and Mobula japanica as inferred from stable isotope analysis. J Mar Biol Assoc UK 90:969-976

Sars GO (1885) Report on the Schizopoda collected by H.M.S. Challenger, during the years 1873-1876. In: Thomson CW, Murray J (eds) Report on the scientific results of the voyage of H.M.S. Challenger, during the years 1873-76. Zoology 37. 13:1-228

Schell SC (1985) Handbook of trematodes of North America north of Mexico. University Press of Idaho, Moscow, ID

Shimazu T (1971) Description of the progenetic metacercaria of Pseudopecoelus japonicus (Allocreadiidae: Trematoda) from Euphausia similis (Euphausiacea: Crustacea) of Suruga Bay. Kisechugaku Zasshi 20:83-86 (in Japanese)

Shimazu T (1972) On the parasitic organisms in a krill, Euphausia similis, from Suriga Bay IV. Metacercariae of the digenetic trematodes. Kisechugaku Zasshi 21: 287-295 (in Japanese)

Shimazu T (1975) Some cestode and acanthocephalan larvae from euphausiid crustaceans collected in the Northern North Pacific Ocean. Bull Jpn Soc Sci Fish 41: 813-821 (in Japanese with English Abstract)

Editorial responsibility: Sven Klimpel, Frankfurt, Germany
Shimazu T (1982) Some helminth parasites of marine planktonic invertebrates. J Nagano-Ken Jun Coll 37:11-29

Shimazu T (2006) Trematodes and cestodes parasitic in euphausiids. Bull Plankton Soc Japan 53:45-53 (in Japanese with English Abstract)

Shimazu T, Kagei N (1978) A metacercaria of the genus Paronatrema (Trematoda; Syncoelliidae) parasitic in Euphausia pacifica (Crustacea; Eupausiidae) from the East China Sea. Zool Mag 87:158-161

Shimazu T, Oshima T (1972) Some larval nematodes from euphausiid crustaceans. In: Takenouti AY (ed) Biological oceanography of the northern North Pacific Ocean. Idemitu Shoten, Tokyo, p 403-409

Shvetsova LS (2004) On a composition of the genus Copiatestes Crowcroft, 1948 (Digenea: Syncoeliidae). Parasitologyca 948:547-551 (in Russian with English Abstract)

Slankis AY, Shevchenko GG (1974) Data on the infestation of planktonic invertebrates with helminth larvae in the western part of the equatorial zone of the Pacific. Canadian Translation of Fisheries and Aquatic Sciences Series No. 5596. Originally published in TINRO 88:129-138

Smith PE, Richardson S (1979) Técnicas modelo para la prospección de huevos y larvas de peces pelágicos. Doc Tec Pesca 175. FAO, Rome (in Spanish)

Villareal LA, Dailey MD (1993) Syncoelium regaleci sp. n. (Digenea: Syncoeliidae) from the branchial cavity of the oarfish (Regalecus glesne). J Helminthol Soc Wash 60: 162-164

Submitted: October 16, 2014; Accepted: June 25, 2015 Proofs received from author(s): August 19, 2015 